\title{
Facts versus Theories: An Everlasting Struggle
}

The Johann Jakob Wepfer Award 2010

Jan van Gijn

Department of Neurology, University Medical Centre Utrecht, Utrecht, The Netherlands

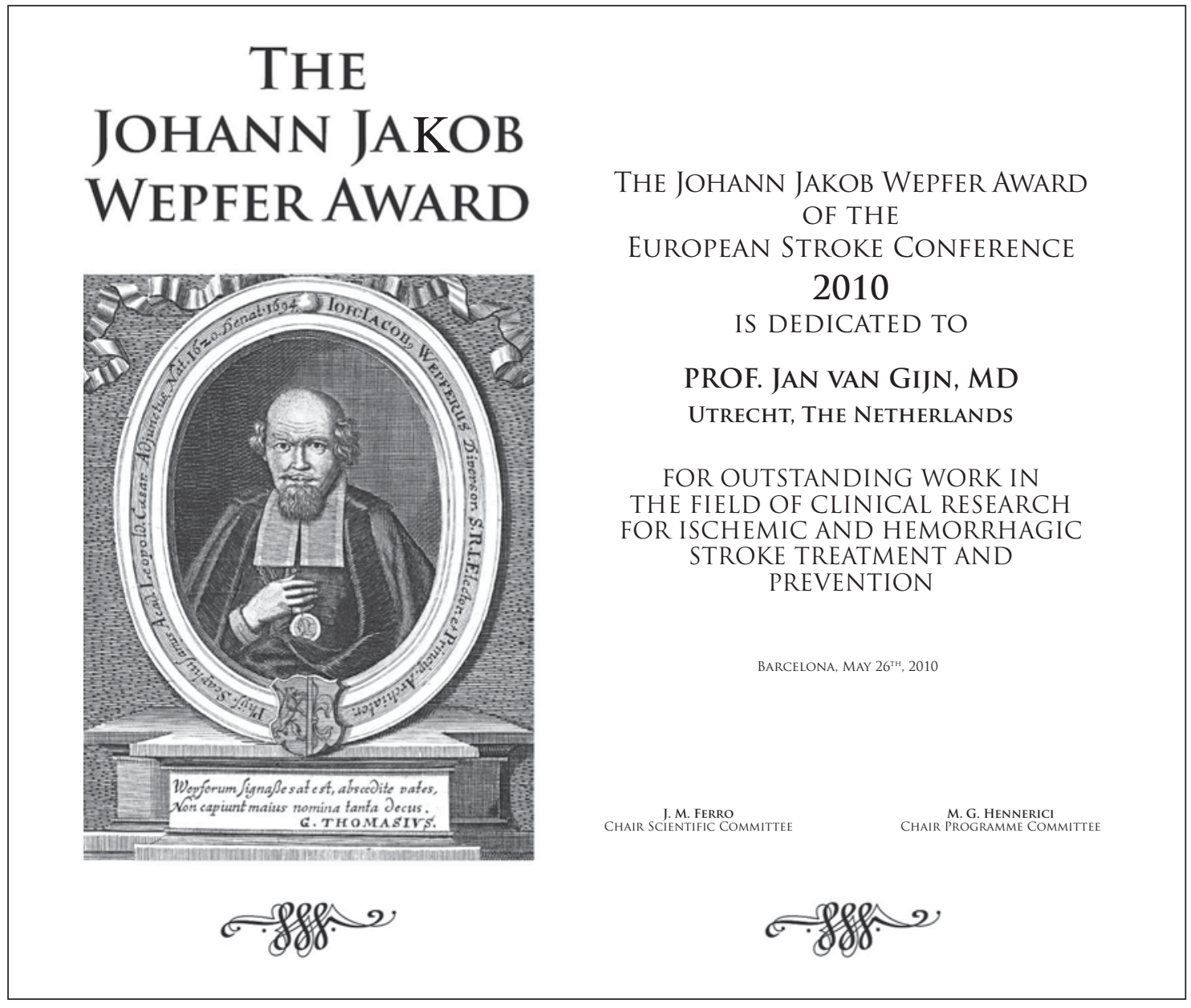

\section{KARGER}

Fax +41613061234 E-Mail karger@karger.ch www.karger.com
(C) 2010 S. Karger AG, Basel

$1015-9770 / 10 / 0304-0330 \$ 26.00 / 0$

Accessible online at:

www.karger.com/ced
J. van Gijn, MD, FRCP, FRCP(Edin), Emeritus Professor of Neurology Department of Neurology, Room G03.228

University Medical Centre Utrecht, Heidelberglaan 100

NL-3584 CX Utrecht (The Netherlands)

Tel. +31 30250 7975, Fax +31 30254 2100, E-Mail J.vanGijn@ umcutrecht.nl 


\section{Key Words}

History of neurology • Johann Jakob Wepfer · Aspirin ·

Subarachnoid haemorrhage $\cdot$ Scientific methods

\begin{abstract}
Rather than a complete overview of the contribution of Utrecht to stroke research, I have selected a few subjects and attempt to put these in historical context. Johann Jakob Wepfer (1620-1695) was unique in that he approached 'apoplexy' through post-mortem observations, in the tradition of Padua. However, the interpretation of his findings in haemorrhagic and especially non-haemorrhagic stroke was still heavily influenced by the authority of Galen's writings. Wepfer's category of 'serous apoplexy' assumed that extravasation of blood serum might lead to compression of brain substance and blockage of 'nerve pores' through which mental 'spirit' was supposed to flow. This notion of 'cerebral congestion' or 'cerebral hyperaemia' lived on, at least to the middle of the 20th century! The pitfalls of theorizing are also evident from recent history (the facile assumption that cerebral ischaemia occurs in the same way as leg ischaemia). By implication, similar errors may well be hidden in present ideas about stroke. Probable or possible examples are the idées reçues that $30 \mathrm{mg}$ of aspirin is less efficacious in the secondary prevention of stroke than $100 \mathrm{mg}$, that vasospasm is the cause of delayed ischaemia after aneurysmal subarachnoid haemorrhage and that perimesencephalic haemorrhage is not caused by rupture of an artery. Physicians still speculate more often than they care to admit.
\end{abstract}

Copyright $\odot 2010$ S. Karger AG, Basel

Three years ago, I retired from the chairmanship of neurology in Utrecht. Coincidentally, it was around that time that two major journals asked our group to summarize the state of the art in acute ischaemic stroke and in subarachnoid haemorrhage, including our own work [1, 2]. After those parting shots, I still see outpatients but very few patients with stroke. As a consequence, my interests are gradually shifting to new areas. On one of these, the borderland between neurology and psychiatry, especially somatoform disorders, I will remain silent. The other new challenge is the history of medicine and of stroke in particular. I will therefore start with a historical perspective. To some extent, this interest is a question of age: the past for me is now larger than the future. On the other hand, we all often forget that we build on the work that has been done by countless generations of predecessors, particularly when we are young. From the times from which writing has been preserved, efforts to understand life and disease have woven an unbroken thread, connecting past, present and future. A study of medical history makes clear that we can learn not only from past achievements, but also from past mistakes.

The history of stroke, like the history of science in general, is not a tale of one discovery after another, not simply a consecutive series of triumphs and of the great men who achieved them. New observations have almost never prompted sudden and radical changes in medical thinking. Rather, in an erratic process with many blind alleys, new ideas were, if not resisted (think of Galileo and Darwin), at least always interpreted in the light of existing theories. Theories about nature provide indispensible scaffolding that helps to support our daily lives: the sun will rise every morning, physical exercise is healthy and sex with strangers may cause disease. From the very beginning of mankind there have been theories about the mechanics of the body and its derangements in disease; those from Europe and the Arabic world are best known to us. Ancient medical heritage converged in the writings of Galen (131-201), which dominated medical teaching throughout the Middle Ages. The first book on diseases of the nervous system, published in Basle in 1549 and written by Jason Pratensis (1486-1558) [3], is still steeped in galenic notions of humoral medicine: stroke (apoplexy) was defined as a condition in which a person is deprived of all motion and sensation, apart from breathing. This means that the admixture of air to the blood still produces life spirit (spiritus vitalis) in the heart, but that for some reason its passage to the brain is blocked, where it should be transformed into mental spirit (spiritus animalis). An important difference with present notions is not only that we would substitute both kinds of spirit by oxygen and glucose, but also that the term 'apoplexy' implied generalized dysfunction of the brain. The treatments advised by Pratensis were in keeping with the fluidist tradition: purging, bloodletting or administration of complicated herbal remedies, by mouth or as ointment.

\section{Johann Jakob Wepfer: Pioneer as well as Child of His Time}

Wepfer (1620-1695) published 4 case histories of apoplexy in his famous 1658 book [4]. In 1675, he published an addendum with 17 new and annotated examples [5]. In 8 of 18 cases with sufficient details the cause of the apoplexy was traumatic (more than once because the subject fell down the stairs in an inebriated state). In his no- 
sology, Wepfer followed the galenic tradition in defining apoplexy according to the clinical manifestations, independent of causation [6]. In 3 of 10 patients with 'spontaneous apoplexy', postmortem examination of the brain showed clotted blood, either as rounded lesions in the brain parenchyma (grumus sanguinis), the size of which Wepfer compared with specific eggs or nuts, or as a halfclotted substance (cruor) between the dura and the arachnoid (tenuis menynx). In his case histories, Wepfer first described the patients with their names and ages, details about their profession and habits, past diseases and symptoms preceding their death. The findings on opening the head, often with an acknowledgement of the colleague who offered him the opportunity, are precise and full of anatomical details, disclosing an intimate knowledge of the structure of the brain.

On reading Wepfer's cases after Pratensis's treatise, written some hundred years before, one feels like being caressed by a fresh wind after having stayed in a stifling room. What Pratensis reproduced was not only an old theory, it was mere theory - a closed system, in which all observations and actions had to be fitted. Wepfer tells the reader what he sees and tries to let these observations speak for themselves. This change represents no less than a quantum leap. It is no longer reasoning from first premises that determines how one should interpret the world (deductive thinking), but the other way around: observations form the starting point, and it is by building on these that one tries to construct general rules (inductive thinking). Undoubtedly, Wepfer owed this attitude not to his initial studies at the universities of Basle and Strasbourg, but to the more advanced and stimulating atmosphere at the University of Padua, where he continued his education between 1644 and 1647 [7]. In Padua, he was confronted with Harvey's doctrine about the circulation of the blood (published in 1628) [8]; it was the subject of demonstrations by the anatomist Johann Vesling. Argumentation and experimentation convinced Wepfer of the validity of Harvey's discovery. What must have most deeply influenced Wepfer was not so much the fact in itself that blood returned to the heart, instead of being 'burned' in the body parts, but the principle that by collecting evidence from careful observations one might build a new theory. Most important, he adopted the Italian tradition of opening the body and skull after death.

But of course Wepfer could not completely disentangle himself from the old ideas. Actually only 18 pages of his 1658 book are devoted to the 4 case histories, the remaining 271 pages to theorizing, in which he went much further than his observations allowed. He systematically at- tacked galenic notions, embodied by the Parisian professor Jean Riolan (1580-1657), especially those about the rete mirabile (as Vesalius had done before him) and the role of the cerebral ventricles in producing spiritus animalis - a role Wepfer attributed to the brain parenchyma. Although he had the foresight to suggest that the 'slimy or fibrous bodies' (corpora sive pituitosa, sive fibrosa) he saw in the arterial walls of non-apoplectic patients might cause apoplexy by an interruption of the blood flow, he held fast to the principle of 'mental spirit' (spiritus animalis) and explained apoplexy by shortage of constituents in blood from which it was made. An even more important remnant of ancient thinking was the notion of 'serous apoplexy' (apoplexia e sero effervescente), Wepfer assumed, with Charles le Pois (Carolus Piso, 1563-1633), that several circumstances might cause extravasation of blood serum, leading to congestion and compression of the brain substance and to blockage of the nerve pores (which were supposed to be hollow). Local symptoms were sometimes mentioned in passing, but unconsciousness remained the cardinal feature of apoplexy. In conclusion, Harvey may have been looking over one of Wepfer's shoulders, Galen was still looking over the other.

\section{Organ-Based Medicine}

We now jump some 150 years ahead to read one of the case histories in a book on apoplexy published in 1811, by Antoine Portal (1742-1832) [9].

Mr. Duntzfeld, a Danish merchant, having arrived in Paris after a sojourn in Spa, where he had drunk much water, suffered from generalised dropsy. The different treatments that I had prescribed, together with my colleague Mr. Demangeon, initially seemed to produce favourable effects. The swellings had disappeared after copious passing of urine. Subsequently the patient nevertheless experiences strong pain in the loins and complete cessation of urine production; the swellings all over the body promptly returned, which led us to suppose there was a disorder of the kidneys, leading to interruption of micturition. Respiration becomes very difficult, Mr. Duntzfeld becomes deeply unconscious, and dies earlier than expected.

The autopsy is performed by Mr. Jean-Paul Martin, in the presence of Mr. Demangeon and me. As we expected, we found a great quantity of water in the abdomen; the kidneys were greatly swollen, soaked and softened, while the right kidney contained firmer parts, some of which were purulent. The chest also contained much water, but in the skull there was only the usual quantity of fluid, between the membranes of the brain as well as in the ventricles. Nevertheless I had thought to find much fluid there, and was convinced that the unconsciousness of the patient was caused by it. In contrast, the blood vessels and sinuses of the brain were full of blood. Undoubtedly it is to this excess of blood that 
one has to attribute the state of unconsciousness the patient passed through during his disease, especially before dying, which was very deep, with difficulty breathing. One can easily see why: the pressure from the excess of water on the blood vessels, especially the veins of the trunk, the abdomen and the chest, through obstructing the return flow of blood, determined the congestion of the brain.

For a contemporary physician the diagnosis is clear: acute glomerulonephritis. Portal had made the same diagnosis, in his own terms. After all, around 1800 fluidism was rapidly being replaced by solidism, organ-based medicine. The impetus had come - again - from Padua, where Giovanni Batista Morgagni (1682-1771) taught pathological anatomy and recorded his lifelong experience of postmortem examinations [10]. The change was taken up and expanded by the French revolutionaries, who modernized hospital care and abolished the division between medicine and surgery $[11,12]$.

Let me return to Portal. Right at the end of the case history he jumps at a conclusion that is difficult to follow for a modern reader. He does not explain - as we would do - the cause of death by a combination of heart failure and pulmonary congestion. Instead, he locates the problem in the brain. Not in the sense that every death ultimately involves brain death, but in that the general excess of fluids had also affected the brain, by causing congestion. The amount of fluid around the brain and in the ventricles may have been normal, other than he expected, writes Portal, but at least he saw that the vessels were congested. Without having been there, I can vouchsafe that Portal and his colleague saw something that was not actually there. Veins may be congested, although that feature will disappear after death, but not arteries or sinuses. Portal saw what he wanted to see. And he wanted to see it because theory dictated it. The theory still was, at least for Portal, that any patient who becomes rapidly unconscious and has difficulty breathing is the victim of apoplexy and that apoplexy is often caused by congestion of the brain. Full stop. Theories are seductive. Portal had Morgagni looking over one shoulder, but Galen was still looking over the other.

\section{The Long Life of 'Cerebral Congestion'}

To cut a long story short, in the course of the 19th century, cerebral softening (ramollissement) was identified as a separate variety of cerebrovascular disease, largely through the work of Léon Rostan (1790-1866) [13], while subsequently the role of atherosclerosis, thrombosis and embolism was to a large extent identified [14]. Also it be- came clear that cerebral haemorrhage and cerebral softening primarily caused focal neurological deficits rather than unconsciousness, deficits that had previously been classified as 'paralysis' and regarded as a more peripheral disorder of the nervous system.

Nevertheless the notion of cerebral congestion lived on. It was conveniently used to explain general symptoms attributed to brain disease, from problems of concentration to drowsiness. At least in Britain, J. Russell Reynolds, editor of the three-volume System of Medicine (1866), dedicated a full chapter to cerebral congestion, with his co-author H.C. Bastian [15]. Sometimes it went under the guise of the more modern sounding term 'hyperaemia'. The famous American neurologist William Hammond (1828-1900) even devoted a monograph to the subject [16], although 4 years later a dissenting monograph appeared, interestingly by the same publisher and in the same format [17]. Cerebral congestion is also included in Gowers' famous textbook as well as in a subsequent version of the System of Medicine, published in $1910[18,19]$. In these last two textbooks, some doubt begins to creep in, but nevertheless the concept held out until 1941, when it appeared in the posthumous publication of the textbook by S.A. Kinnier Wilson (1878-1937). Apparently the author did not dare to ignore the issue, although he lamely began with 'consideration of the topic of cerebral congestion or hyperaemia leads into a field of pathology not yet cleared of obscurity' [20]. Theories are tenacious. Hughlings Jackson may have been looking over one of Wilson's shoulders, but Galen still peeped over the other.

\section{The Era of Evidence-Based Medicine: Free of Theorizing?}

Is today's stroke medicine free from galenism? True, we no longer believe in ancient notions such as the equilibrium between body fluids, the rete mirabile at the base of the brain or mental pneuma governing our actions from the cerebral ventricles. But despite our professed empiricism, we are still secretly fond of theories. Theories are convenient because they structure our mental world. Therefore, we tend to ignore the truth that theories are intrinsically unfinished and temporary, because often new observations must be accommodated to make new theories or at least update the old ones. Sometimes additional observations leave the theory intact, such as Marcello Malpighi's (1628-1694) finding of capillaries, the missing link in Harvey's theory of circulation. But in oth- 
er instances, the theory has to be modified or even abandoned, as occurred when the advent of CT scanning in the 1970s disproved the idea that haemorrhages into the ventricular system were always lethal (Galen again?). Unfortunately, abandoning old concepts is painful; most people prefer to stick to their old beliefs. From the moment that reconstruction of the internal carotid artery became feasible (fig. 1) [21], surgeons all over the world adopted the procedure, in patients with or even without transient ischaemic attacks (TIAs), in the belief that blood flow to the brain needed to be improved in the same way as in arterial disease of the legs, in spite of anatomical, physiological and experimental observations suggesting that despite the similarity of the underlying arterial disease the pathophysiology of these two disorders was quite different (the existence of collaterals, the invariability of the blood flow to the brain and the failure to produce TIAs by lowering the blood pressure). At that time, some talked about 'cerebral claudication'. It took the courage and persistence of Charles Warlow to mount - and complete - a clinical trial and largely settle the issue, eventually together with colleagues from North America [22, 23].

I shall now turn from the present to the future and venture to suggest a few areas where missing or even actual observations may or should lead to changes in the theoretical framework of cerebrovascular disease.

\section{Missing Observations: The Dose of Aspirin}

The dose of aspirin in stroke prevention was a hotly debated subject around $1990[24,25]$, but the discussion has now died down. Current wisdom, in the form of meta-analysis, the highest echelon in the hierarchy of evidence-based medicine, professes 'overall, among 3,570 patients in three trials directly comparing aspirin $>75 \mathrm{mg}$ daily vs. aspirin $<75 \mathrm{mg}$ daily there was no significant difference between the different aspirin regimens. However, aspirin doses of $<75 \mathrm{mg}$ have been less widely assessed than doses of 75-150 mg daily, so there remains uncertainty about whether such low doses are as effective as daily doses of $>75 \mathrm{mg}$ ' [26].

So uncertainty still remains - but absence of proof is not the same as proof of absence. Indeed there are good reasons to believe that $30 \mathrm{mg}$ of aspirin may be even more efficacious than higher doses in the prevention of ischaemic stroke and other major vascular events.

Aspirin (its proper, generic name is acetylsalicylic acid) is a double-edged sword because it inhibits not only

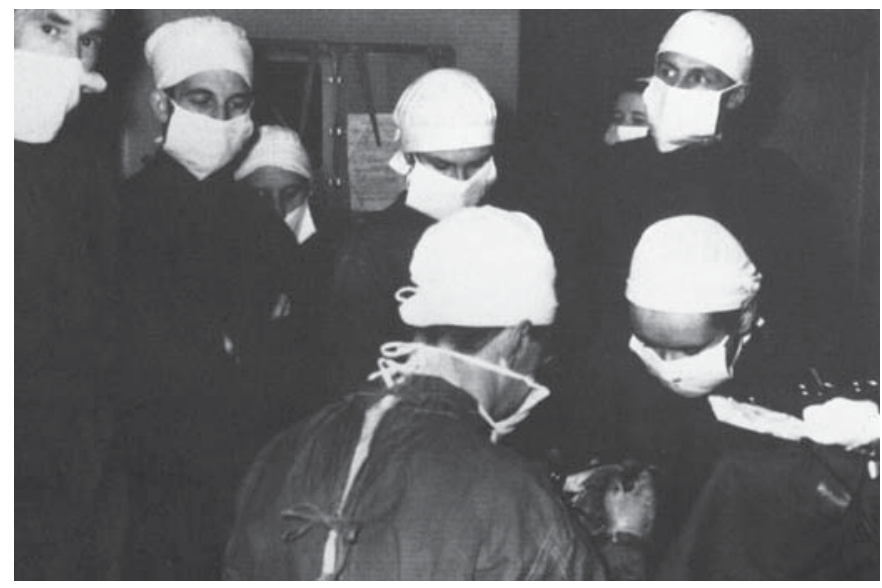

Fig. 1. One of the first operations in which the left internal carotid artery was reconstructed in a patient with recurrent transient ischaemic attacks, by Eastcott and Rob in St. Mary's Hospital, London, in 1954 [21]. The patient was a 66-year-old woman who had experienced 33 attacks of right hemiplegia and aphasia, together with blindness in the left eye. A segment of the artery, almost completely occluded by atheroma, was resected; repair was possible by end-to-end anastomosis. In retrospect, this was probably one of the rare instances in which the pathogenesis of the ischaemic attacks was through haemodynamic failure rather than thromboembolism.

the production of the thromboxane $\mathrm{A}_{2}$ in platelets, which promotes platelet aggregation and subsequent thrombosis, but also, in endothelial cells, the production of prostacyclin, which counteracts platelet aggregation (fig. 2). Given that endothelial cells can resynthesize the target enzyme, this opens the possibility that low doses of aspirin can inhibit the production of thromboxane while the production of prostacyclin remains largely intact. And indeed in healthy volunteers we have demonstrated, as far back as in 1987, that daily ingestion of $30 \mathrm{mg}$ of aspirin resulted in extremely low levels of the metabolite of thromboxane $\mathrm{A}_{2}$, whereas the metabolite of prostacyclin was unaffected (fig. 3) [27]. Subsequently the complete suppression of thromboxane production with $30 \mathrm{mg}$ of aspirin after a few days has been confirmed in patients with TIAs and ischaemic stroke [28].

Of course the proof of the pudding - the theory - is in the empiricism of clinical trials. In the 1980s, we performed a double-blind study in patients with TIAs or non-disabling strokes, in which we compared the efficacy of $30 \mathrm{mg}$ and almost $300 \mathrm{mg}$ of aspirin in preventing major vascular events (fig. 4) [29]. At the close of the trial, after 36 months of follow-up, there was no difference, but 


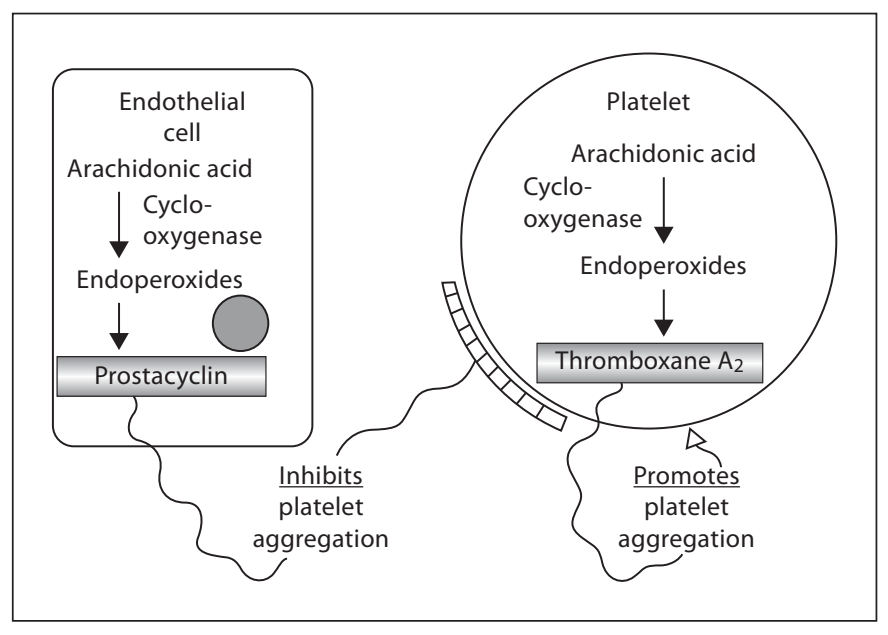

Fig. 2. The double action of acetylsalicylic acid. Transfer of the acetyl group to the enzyme cyclo-oxygenase permanently inactivates the enzyme. In platelets the enzyme catalyses the production of the pro-aggregation substance thromboxane $A_{2}$, but in endothelial cells the end product is an anti-aggregation substance, prostacyclin. Endothelial cells can resynthesize cyclo-oxygenase, thanks to their nucleus, but platelets cannot. Adapted from van Gijn (1987) [24].

up to 30 months, before the number of participating patients became very small, there was just a suggestion of an advantage of the lower dose. Of course the difference may be fortuitous and false, but unfortunately the matter has been left there, buried by a mass of data about higher doses of aspirin and by intense marketing of new, proprietary drugs with antiplatelet actions. And even in the Netherlands, the standard dose of aspirin has gone up to 80 or $100 \mathrm{mg}$ daily, partly because general practitioners complained about the confusion generated by the difference in prescriptions from cardiologists and neurologists.

Does prostacyclin matter at all from the clinical point of view? There is ample evidence of an increased risk of myocardial infarction by the use of analgesic agents that selectively inhibit cyclo-oxygenase type 2 (the type also present in endothelial cells) [30]; there is a definite possibility that this deleterious effect is brought about by a disturbed balance between thromboxane and prostacyclin in the vessel wall [31]. To sum up, the conclusion that the medical community should stick to higher doses of aspirin than $75 \mathrm{mg}$ may be warranted by the robustness of current evidence, but the matter should by no means be regarded as closed. It is a pragmatic point of view, not a definitive scientific fact.

Facts versus Theories - An Everlasting Struggle

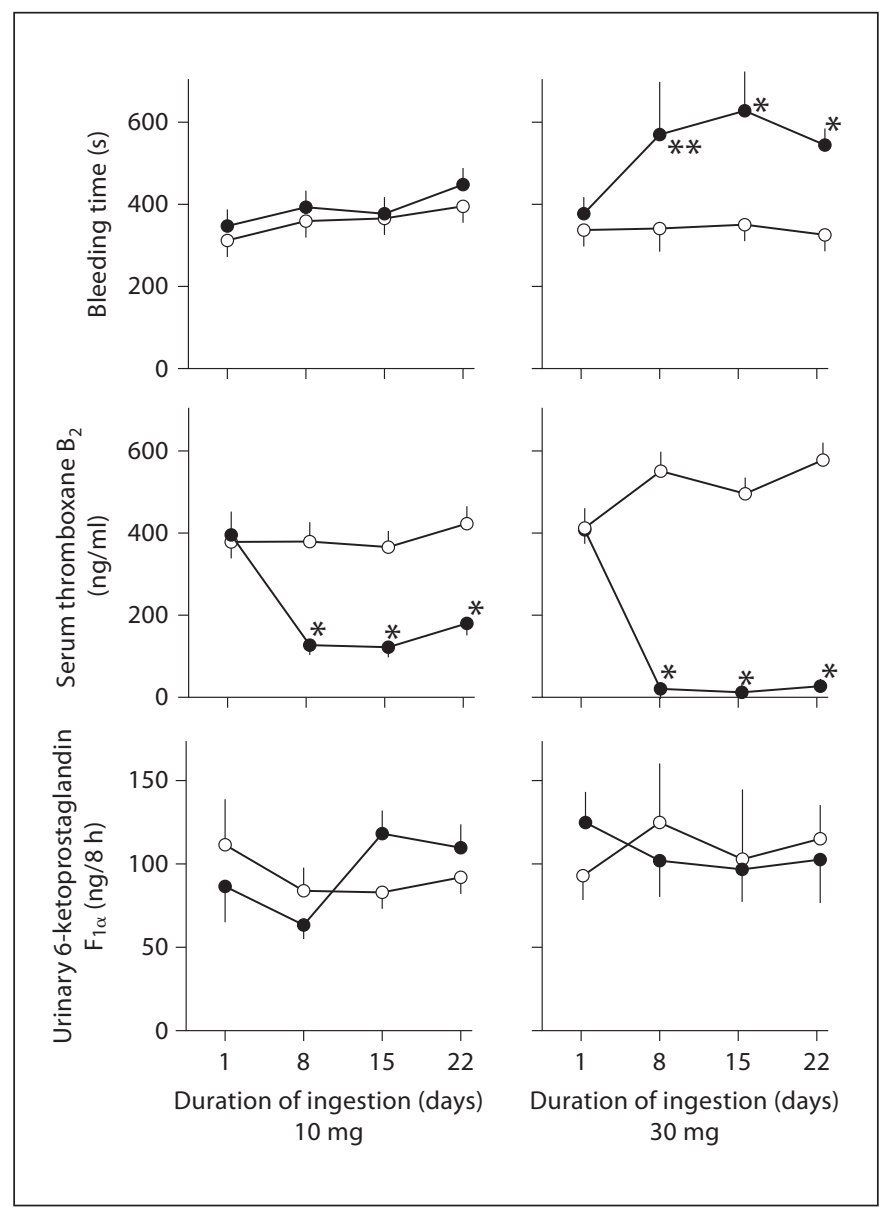

Fig. 3. The effect of daily ingestion of 10 or $30 \mathrm{mg}$ of aspirin in healthy volunteers, compared with placebo, in a double-blind design [27]. Effects are shown on bleeding time, levels of thromboxane $\mathrm{B}_{2}$ (metabolite of thromboxane $\mathrm{A}_{2}$ ) in serum and urine levels of 6-ketoprostaglandin $\mathrm{F}_{1} \alpha$, a stable metabolite of prostacyclin. Open circles indicate placebo, closed symbols aspirin.

\section{Aneurysmal Subarachnoid Haemorrhage}

Another cerebrovascular disorder that has been at the centre of our attention is subarachnoid haemorrhage. This field has definitely been advanced by a number of clinical trials. One we did ourselves took place around 1980, when I was still working in Rotterdam, on prevention of rebleeding by administration of tranexamic acid, an antifibrinolytic agent [32]. The study lasted several years; during the initial phase, my colleagues and I, who had no training at all in clinical epidemiology, made almost every conceivable mistake, but each time we were somehow saved. Partly we had to thank our neurosurgical collaborators in Glasgow, Graham

Cerebrovasc Dis 2010;30:330-339 


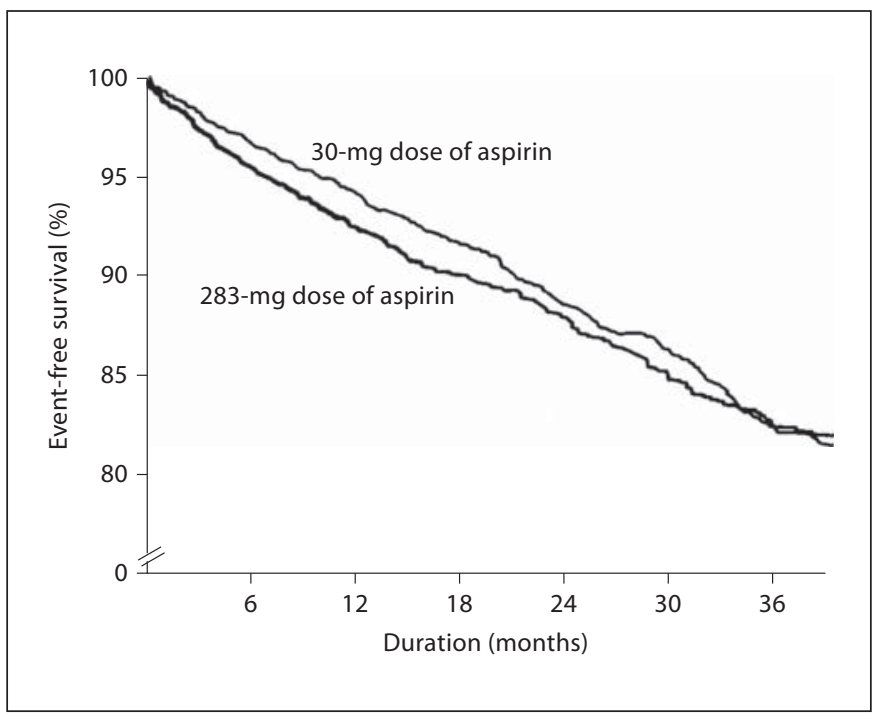

Fig. 4. Results of the Dutch TIA trial, in which 3,131 patients with TIA or non-disabling stroke were randomized to either 30 or 283 $\mathrm{mg}$ of aspirin, in a double-blind design [29]. The composite end point consisted of any stroke or myocardial infarction or vascular death.

Teasdale and Ken Lindsay, and partly the authors of some essential books on clinical research [33, 34]. Had the rate of rebleeding been the primary measure of outcome, as we had originally and naively planned, the result would have been wonderful. But since we changed it to overall function, as measured by means of the Glasgow Outcome Scale, we found no difference between those treated with tranexamic acid and the placebo group. The explanation was that the prevention of subsequent aneurysm ruptures was offset by an excess of ischaemic complications. A hard lesson had been learned. We might have reached a wrong conclusion by narrowly defined outcome criteria. Physicians do not treat specific complications but individuals (literally: that which cannot be divided).

\section{'Vasospasm'}

Since then, very early endovascular occlusion by means of platinum coils has almost obviated the need for drug treatment to prevent rebleeding, but ischaemic complications still pose a great problem. Although administration of nimodipine decreases the risk by about one third, according to a large British trial [35], the remaining proportion is so far resistant to interventions. Unfortu- nately the pathogenesis of these ischaemic complications after aneurysm rupture is obscure, despite the tendency of many surgeons and physicians to attribute them to 'vasospasm'. This common notion is based on the observation that ischaemic complications after aneurysm rupture may coincide with narrowing of major cerebral arteries and their branches on angiography, but this correlation meets few - if any - of the criteria for causality [36]. In contrast, several observations argue against a causal relationship [37, 38]:

- delayed cerebral ischaemia may occur without vascular narrowing $[39,40]$;

- arterial narrowing may occur without ischaemic complications [39, 41];

- the temporal relationship between arterial narrowing and the development of ischaemic complications is poor [42];

- nimodipine reduces ischaemic complications but not vascular narrowing [35];

- clazosentan reduces vascular narrowing but not ischaemic complications [43];

- finally, several other factors are associated with ischaemic complications: initial loss of consciousness [44], the amount of subarachnoid blood on CT scanning (but not its location) [45, 46], hypovolaemia [47], hyponatraemia [48] and treatment with antifibrinolytic drugs [32].

The issue is further compounded by two other problems. Firstly, observers may disagree on the presence or absence of arterial narrowing [49]. Secondly, arterial narrowing may be caused by factors other than spasm of the muscular layer, such as swelling of the endothelial and subendothelial layer [50], or microthrombosis [51]. The persistent belief in 'vasospasm' has even led to a habit of regarding it as the cause of any episode of clinical deterioration that cannot be attributed to rebleeding, metabolic factors or hydrocephalus [52]. Prematurely, the notion has been translated into action, through attempts to increase the arterial diameter by medical or endovascular interventions. In brief, cerebral ischaemia after aneurysmal haemorrhage is a complex, ill-understood phenomenon. The common adoption of the term 'vasospasm' is not only a fig leaf under which general ignorance remains conveniently hidden, it actually impedes progress because it stops us thinking about other possibilities which might better fit the facts. 


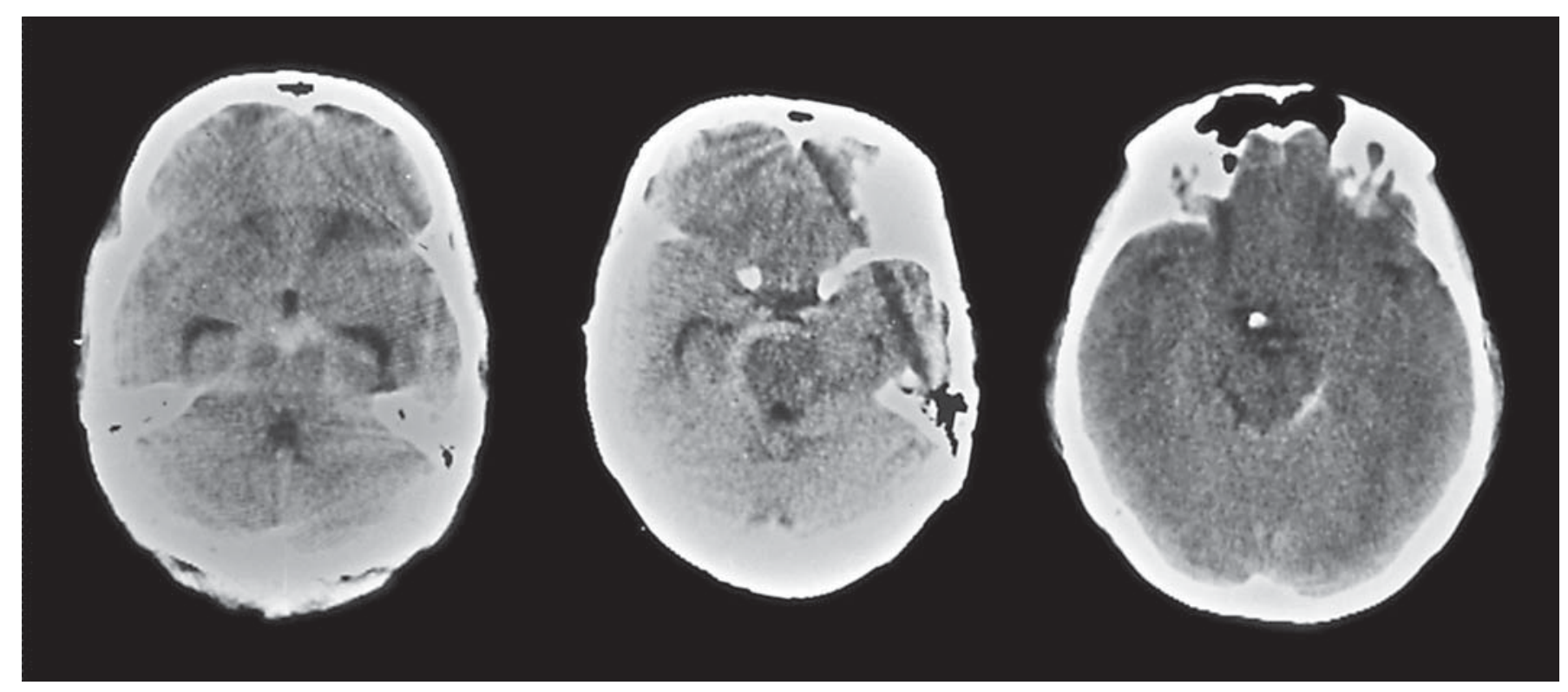

Fig. 5. Patterns of non-aneurysmal perimesencephalic haemorrhage, as illustrated in our initial publication [53]. The centre of the haemorrhage might be in the interpeduncular cistern (left; this later proved to be the most common pattern), ambient cistern (middle) or quadrigeminal cistern (right). There is no extension to the ventricular system (other than by sedimentation) or to anterior and lateral cisterns.

\section{Perimesencephalic Haemorrhage}

It struck us in the 1980s that 13 patients with spontaneous subarachnoid haemorrhage but negative angiograms had patterns of haemorrhage on early CT scans that differed from those in patients with ruptured aneurysms [53]: the centre of the haemorrhage might be in the interpeduncular cistern (this later proved to be the most common variety), ambient cistern or quadrigeminal cistern (fig. 5). There is no extension to the ventricular system (other than by sedimentation of red cells floating in the cerebrospinal fluid) or to the anterior and lateral cisterns. Another unusual feature was that the headache tended to come on in minutes rather than seconds. Loss of consciousness was not reported, whereas this occurs in about one third of patients with ruptured aneurysms. Subsequent observations, in larger series of patients, confirmed the impression that the outcome was invariably good, other than in patients in whom angiography also failed to show an aneurysm, but in whom the pattern of bleeding suggested a ruptured aneurysm [54]. Angiography cannot be omitted, however, because in about 1 of 20 patients with a perimesencephalic pattern of haemorrhage the cause is still an aneurysm, of the posterior circulation, almost invariably from the top of the basilar ar- tery $[53,55]$. As the sensitivity of CT angiography improved, catheter angiography is no longer necessary to exclude such an aneurysm [56]. It turned out that the surface of the midbrain is not the only place where this type of haemorrhage may occur, as it has also been found anterior to the pons [57].

What do we conclude from all this? The limited extent of the haemorrhage, so unlike most arterial ruptures, the more gradual onset of the headache that is so often reported, the lack of complications other than occasionally hydrocephalus [58], and the invariably excellent outcome, with a normal life expectancy [59], all led us to suspect rupture of a low-pressure vessel - a superficial vein or capillary. This is mere speculation - maybe the future will prove us wrong. But at least we can tell our patients it will not occur again. The theory of 'a ruptured vein' is a harmless substitute for actual anatomical observations and it does not impede the advancement of patient care. We should remain aware that other theories are definitely harmful, such as narrow vessels that need to be dilated by force. On many occasions we are not the hard-boiled empiricists we believe ourselves to be. Galen still lurks among us. 


\section{Epilogue}

Of course I am flattered - if not astounded - to have been awarded the 2010 Wepfer prize. But I have not been alone in stroke research. During my entire career I have had splendid teachers and colleagues, in Rotterdam (1971-1983) as well as in Utrecht and Edinburgh (19832007). To name a few, in alphabetical order: Ale Algra, Hans van Crevel, Jaap Kappelle, Peter Koudstaal, Gabriel Rinkel, Peter Sandercock, Arthur Staal, Rien Vermeulen,
Charles Warlow (who was awarded this prize in 2007), Eelco Wijdicks and Bart van der Worp. They share in this honour.

\section{Acknowledgement}

I thank Charles Warlow for critical comments on an earlier version of this text.

\section{References}

1 Van der Worp HB, van Gijn J: Acute ischemic stroke (clinical practice). N Engl J Med 2007; 357:572-579.

2 van Gijn J, Kerr RS, Rinkel GJE: Subarachnoid haemorrhage. Lancet 2007;369:306318.

3 Pratensis J: De cerebri morbis. Basle, Henricus Petri, 1549.

4 Wepfer JJ: Observationes anatomicae, ex cadaveribus eorum, quos sustulit apoplexia, cum exercitatione de eius loco affecto. Schaffhausen, Suteri, 1658.

5 Wepfer JJ: Observationes anatomicae, ex cadaverum eorum, quos sustulit apoplexia. Cum exercitatione de eius loco affecto. Novae ed. Schaffhausen, Onophrius, 1675.

-6 Karenberg A: Johann Jakob Wepfers Buch über die Apoplexie (1658). Kritische Anmerkungen zu einem Klassiker der Neurologie. Nervenarzt 1998;69:93-98.

7 Karenberg A: Johann Jakob Wepfer (16201695). J Neurol 2004;251:501-502.

8 Harvey W: Exercitatio anatomica de motu cordis et sanguinis in animalibus. Frankfurt, Fitzer, 1628.

9 Portal A: Observations sur la nature et le traitement de l'apoplexie, et sur les moyens de la prévenir. Paris, Crochard, 1811.

10 Morgagni GB: De sedibus et causis morborum per anatomen indigatis libri quinque. Venice, ex typographica Remondiana, 1761.

11 Ackerknecht EH: Medicine at the Paris Hospital 1794-1848. Baltimore, The Johns Hopkins Press, 1967.

12 Hannaway C, La Berge A (eds): Constructing Paris Medicine. Amsterdam, Rodopi, 1998.

13 Rostan L: Recherches sur le ramollissement du cerveau. Ouvrage dans lequel on s'efforce de distinguer les diverses affections de ce viscère par des signes caractéristiques. Paris, Béchet, 1820.

14 Warlow C, van Gijn J, Dennis M, Wardlaw J, Bamford J, Hankey G, et al: Stroke - Practical Management, 3rd ed. Oxford, Blackwell, 2008.
15 Russell Reynolds J, Bastian HC: Congestion of the brain; in Russell Reynolds J (ed): A System of Medicine. Philadelphia, Lippincott, 1866, vol 2, pp 413-429.

16 Hammond WA: Cerebral Hyperaemia. New York, Putnam, 1878.

17 Buckley CF: Cerebral Hyperaemia - Does It Exist? New York, Putnam, 1882.

18 Gowers WR: A Manual of Diseases of the Nervous System. London, Churchill, 1888.

19 Hill L: The experimental pathology of the cerebral circulation; in Albutt C, Rolleston HD (eds): A System of Medicine. London, Macmillan, 1910, vol 8, pp 4-37.

20 Kinnier Wilson SA: Cerebral hyperaemia; in Kinnier Wilson SA, Bruce NA (eds): Neurology. London, Arnold, 1941, vol 2, pp 10611063.

21 Eastcott HHG, Pickering GW, Rob CG: Reconstruction of internal carotid artery in a patient with intermittent attacks of hemiplegia. Lancet 1954;264:994-996.

22 Warlow C: Carotid endarterectomy: does it work? Stroke 1984;15:1068-1076.

23 Rothwell PM, Eliasziw M, Gutnikov SA, Fox AJ, Taylor DW, Mayberg MR, et al: Analysis of pooled data from the randomised controlled trials of endarterectomy for symptomatic carotid stenosis. Lancet 2003;361: 107-116.

24 van Gijn J: What dose of aspirin is most likely to reduce the risk of stroke?; in Warlow C, Garfield J (eds): More Dilemmas in the Management of the Neurological Patient. Edinburgh, Churchill Livingstone, 1987, vol 1, pp 145-155.

25 Dyken ML, Barnett HJM, Easton JD, Fields WS, Fuster V, Hachinski V, et al: Low-dose aspirin and stroke. 'It ain't necessarily so'. Stroke 1992;23:1395-1399.

26 Baigent C, Sudlow C, Collins R, Peto R, for the Antithrombotic Trialists Collaboration: Collaborative meta-analysis of randomised trials of antiplatelet therapy for prevention of death, myocardial infarction, and stroke in high risk patients. BMJ 2002;324:71-86.
27 Kallmann R, Nieuwenhuis HK, de Groot PG, van Gijn J, Sixma JJ: Effects of low doses of aspirin, $10 \mathrm{mg}$ and $30 \mathrm{mg}$ daily, on bleeding time, thromboxane production and 6-ketoPGF1 alpha excretion in healthy subjects. Thromb Res 1987;45:355-361.

28 Dippel DW, van Kooten F, Leebeek FW, van Vliet HH, Mehicevic A, Li SS, et al: What is the lowest dose of aspirin for maximum suppression of in vivo thromboxane production after a transient ischemic attack or ischemic stroke? Cerebrovasc Dis 2004;17:296-302.

29 The Dutch TIA Trial Study Group: A comparison of two doses of aspirin ( $30 \mathrm{mg}$ vs 283 $\mathrm{mg}$ a day) in patients after a transient ischemic attack or minor ischemic stroke. $\mathrm{N}$ Engl J Med 1991;325:1261-1266.

30 Jüni P, Nartey L, Reichenbach S, Sterchi R, Dieppe PA, Egger M: Risk of cardiovascular events and rofecoxib: cumulative meta-analysis. Lancet 2004;364:2021-2029.

31 Wadman M: How does a painkiller harm the heart? Nature 2006;441:262.

32 Vermeulen M, Lindsay KW, Murray GD, Cheah F, Hijdra A, Muizelaar JP, et al: Antifibrinolytic treatment in subarachnoid hemorrhage. N Engl J Med 1984;311:432-437.

33 Wulff HR: Rational Diagnosis and Treatment - An Introduction to Clinical Decision-Making. Oxford, Blackwell, 1981.

34 Schwartz D, Flamant R, Lellouch J: Clinical Trials. London, Academic Press, 1980.

35 Pickard JD, Murray GD, Illingworth R, Shaw MD, Teasdale GM, Foy PM, et al: Effect of oral nimodipine on cerebral infarction and outcome after subarachnoid haemorrhage: British aneurysm nimodipine trial. BMJ 1989;298:636-642.

36 Hill AB: Principles of Medical Statistics. London, The Lancet, 1967.

37 Millikan CH: Cerebral vasospasm and ruptured intracranial aneurysm. Arch Neurol 1975;32:433-449. 
38 Vergouwen MDI, Vermeulen M, van Gijn J, Rinkel GJE, Wijdicks EFM, Muizelaar JP, et al: Definition of delayed cerebral ischemia after aneurysmal subarachnoid hemorrhage as an outcome event in clinical trials and observational studies - Proposal of a multidisciplinary research group. Submitted.

- 39 Rabinstein AA, Friedman JA, Weigand SD, McClelland RL, Fulgham JR, Manno EM, et al: Predictors of cerebral infarction in aneurysmal subarachnoid hemorrhage. Stroke 2004;35:1862-1866.

- 40 Weidauer S, Lanfermann H, Raabe A, Zanella F, Seifert V, Beck J: Impairment of cerebral perfusion and infarct patterns attributable to vasospasm after aneurysmal subarachnoid hemorrhage: a prospective MRI and DSA study. Stroke 2007;38:1831-1836.

-41 Lam JMK, Smielewski P, Czosnyka M, Pickard JD, Kirkpatrick PJ: Predicting delayed ischemic deficits after aneurysmal subarachnoid hemorrhage using a transient hyperemic response test of cerebral autoregulation. Neurosurgery 2000;47:819-825.

-42 Minhas PS, Menon DK, Smielewski P, Czosnyka M, Kirkpatrick PJ, Clark JC, et al: Positron emission tomographic cerebral perfusion disturbances and transcranial Doppler findings among patients with neurological deterioration after subarachnoid hemorrhage. Neurosurgery 2003;52:1017-1022.

-43 Macdonald RL, Kassell NF, Mayer S, Ruefenacht $\mathrm{D}$, Schmiedek $\mathrm{P}$, Weidauer $\mathrm{S}$, et al: Clazosentan to overcome neurological ischemia and infarction occurring after subarachnoid hemorrhage (CONSCIOUS-1): randomized, double-blind, placebo-controlled phase 2 dose-finding trial. Stroke 2008;39:3015-3021.
-44 Hop JW, Rinkel GJE, Algra A, van Gijn J: Initial loss of consciousness and risk of delayed cerebral ischemia after aneurysmal subarachnoid hemorrhage. Stroke 1999;30: 2268-2271.

45 Öhman J, Servo A, Heiskanen O: Risks factors for cerebral infarction in good-grade patients after aneurysmal subarachnoid hemorrhage and surgery: a prospective study. J Neurosurg 1991;74:14-20.

-46 Brouwers PJAM, Wijdicks EFM, van Gijn J: Infarction after aneurysm rupture does not depend on distribution or clearance rate of blood. Stroke 1992;23:374-379.

-47 Wijdicks EFM, Vermeulen M, Hijdra A, van Gijn J: Hyponatremia and cerebral infarction in patients with ruptured intracranial aneurysms: is fluid restriction harmful? Ann Neurol 1985;17:137-140.

48 Wijdicks EFM, Vermeulen M, ten Haaf JA, Hijdra A, Bakker WH, van Gijn J: Volume depletion and natriuresis in patients with a ruptured intracranial aneurysm. Ann Neurol 1985;18:211-216.

49 Eskesen V, Karle A, Kruse A, Kruse Larsen C, Praestholm J, Schmidt K: Observer variability in assessment of angiographic vasospasm after aneurysmal subarachnoid haemorrhage. Acta Neurochir (Wien) 1987; 87:54-57.

50 Hughes JT, Schianchi PM: Cerebral artery spasm - A histological study at necropsy of the blood vessels in cases of subarachnoid hemorrhage. J Neurosurg 1978;48:515-525.

51 Vergouwen MDI, Vermeulen M, Coert BA, Stroes ES, Roos YBWEM: Microthrombosis after aneurysmal subarachnoid hemorrhage: an additional explanation for delayed cerebral ischemia. J Cereb Blood Flow Metab 2008;28:1761-1770.
52 van Gijn J, Hijdra A, Wijdicks EFM, Vermeulen M, van Crevel H: Acute hydrocephalus after aneurysmal subarachnoid hemorrhage. J Neurosurg 1985;63:355-362.

- 53 van Gijn J, van Dongen KJ, Vermeulen M, Hijdra A: Perimesencephalic hemorrhage: a nonaneurysmal and benign form of subarachnoid hemorrhage. Neurology 1985;35: 493-497.

-54 Rinkel GJE, Wijdicks EFM, Hasan D, Kienstra GE, Franke CL, Hageman LM, et al: Outcome in patients with subarachnoid haemorrhage and negative angiography according to pattern of haemorrhage on computed tomography. Lancet 1991;338:964-968.

55 Rinkel GJE, Wijdicks EFM, Vermeulen M, Ramos LMP, Tanghe HL, Hasan D, et al: Nonaneurysmal perimesencephalic subarachnoid hemorrhage: $\mathrm{CT}$ and MR patterns that differ from aneurysmal rupture. AJNR Am J Neuroradiol 1991;12:829-834.

56 Ruigrok YM, Rinkel GJE, Buskens E, Velthuis BK, van Gijn J: Perimesencephalic hemorrhage and CT angiography - A decision analysis. Stroke 2000;31:2976-2983.

- 57 Wijdicks EFM, Schievink WI, Miller GM: Pretruncal nonaneurysmal subarachnoid hemorrhage. Mayo Clin Proc 1998;73:745752 .

-58 Rinkel GJE, Wijdicks EFM, Vermeulen M, Tans JTJ, Hasan D, van Gijn J: Acute hydrocephalus in nonaneurysmal perimesencephalic hemorrhage: evidence of CSF block at the tentorial hiatus. Neurology 1992;42: 1805-1807.

59 Greebe P, Rinkel GJE: Life expectancy after perimesencephalic subarachnoid hemorrhage. Stroke 2007;38:1222-1224. 